\title{
Problematika Pengelolaan Penyelenggaraan Umrah di Kota Surakarta
}

\author{
Akhmad Anwar Dani \\ IAIN Surakarta, Indonesia \\ Email: a.anwar.d@gmail.com
}

\begin{abstract}
This article focuses on mapping of the problems in the implementation of umrah governing in Surakarta in 2017 either on the side of the Indonesian Ministry of Religious Affairs as the regulator, umrah travel agencies as the agent of umrah travel management (PPIHU) or umrah pilgrims as the consumer. Using descriptive qualitative method the research found that the problems that arise involved stake holders were interrelated one to the others. The most fundamental problem which trigger the emergence of further problems was the uncertain regulatory environment of Umrah management by the Indonesian Ministry of Religious Affairs at level district or city. The findings of this study are expected to be a source of study on improving of the umrah governing in the future.
\end{abstract}

Keywords : Problems; Umrah Management; Umrah Governing.

\begin{abstract}
ABSTRAK
Artikel ini fokus pada pemetaan masalah-masalah yang muncul dalam penyelenggaraan ibadah umrah di kota Surakarta pada tahun 2017 baik pada sisi Kementerian Agama selaku regulator, biro perjalanan haji umrah sebagai Penyelenggara Perjalanan Ibadah Haji Umrah (PPIHU) dan jamaah umrah sebagai konsumen. Dengan menggunakan metode kualitatif deskriptif ditemukan bahwa masalah yang muncul pada setiap pihak yang terlibat saling terkait antara satu dengan yang lain. Masalah yang paling mendasar yang memicu munculnya masalah yang lain adalah belum jelasnya regulasi pengelolaan ibadah umrah pada Kementerian Agama di tingkat kabupaten/kota. Temuan penelitian ini diharapkan dapat menjadi bahan kajian perbaikan tata kelola umrah pada masa mendatang.
\end{abstract}

Kata kunci : Problematika; Manajemen Umrah; Penyelenggaraan Umrah.

\section{PENDAHULUAN}

Umrah sering disebut sebagai haji kecil karena syarat-syarat dan ketentuan pelaksanaannya mirip dengan haji, kecuali pada beberapa bagian yang berbeda seperti wuquf di Arafah, mabit di Mina dan melempar Jumrah (Al-Albani, 1994). Selain rukunnya yang berbeda, waktu pelaksanaan haji dengan umrah pun berbeda. Haji hanya dilakukan pada waktu tertentu, sedangkan umrah dapat dilakukan kapan saja. Kondisi ini menyebabkan umrah lebih fleksibel dan berpotensi untuk dilakukan berulang kali dalam satu tahun.

Sejak tahun 2010 animo masyarakat untuk melaksanakan ibadah haji

Diterima: Desember 2017. Disetujui: Juni 2018. Dipublikasikan: Juni 2018 
meningkat hingga 100\% sementara kuota pemberangkatan haji yang ditetapkan oleh kerajaan Arab Saudi tidak selaras dengan jumlah pendaftar haji. Kondisi ini tentu memunculkan fenomena daftar tunggu haji yang semakin hari semakin panjang. Kondisi ini diperparah dengan pemotongan kuota jamaah haji sebesar $20 \%$ pada tahun 2013 karena proses perluasan Masjidil Haram (PHU Kemenag, 2017a). Hal ini memperpanjang daftar tunggu pelaksanaan ibadah haji hingga puluhan tahun. Lamanya waktu tunggu pelaksanaan haji memicu masyarakat untuk menunaikan ibadah umrah sebagai alternatif haji, walaupun secara syariat umrah tidak dapat menggugurkan kewajiban melaksanakan haji.

Berbeda dengan pelaksanaan ibadah haji yang dominan dikelola oleh pemerintah lewat Direktorat Penyelenggaraan Haji-Umrah Kementerian Agama, penyelenggaraan umrah diserahkan sepenuhnya kepada swasta. Pihak kementerian agama hanya sebagai pengawas dan pembina saja sebagaimana diatur dalam PP Nomor 79 tahun 2012 tentang penyelenggaraan ibadah haji. Hal ini memicu perkembangan biro penyelenggara umrah dan haji plus yang meningkat secara signifikan setiap tahun.

Namun patut disayangkan, tumbuhnya usaha penyelenggaraan umrah dan haji plus tidak seiring dengan ketersediaan SDM profesional baik dalam proses pembimbingan ataupun manajerial pengelolaan usaha tersebut. Hal ini bisa dilihat dari banyaknya kasus-kasus pelanggaran yang terjadi dalam penyelenggaraan umrah oleh biro perjalanan swasta. Masalah dalam penyelenggaraan umrah tidak hanya disebabkan oleh faktor SDM saja, namun juga persaingan usaha diantara penyelenggara umrah yang juga memicu permasalahan lain seperti harga perjalanan yang dibuat sangat murah untuk memikat banyak jamaah. Harga yang sangat murah bahkan jauh dibawah standar berdampak pada buruknya layanan yang diberikan kepada jamaah. Pada beberapa kasus banyak jamaah yang ditelantarkan bahkan tidak bisa kembali ke tanah air karena penyelenggara kehabisan dana untuk penyediaan transportasi pulang.

Pada kasus lain banyak penyelenggara palsu yang sejak awal bermaksud menipu calon jamaah umrah dengan iming-iming harga murah dan kualitas layanan standar. Kasus ini pada akhirnya merugikan calon jamaah sendiri. Fenomena ini terjadi hampir merata di seluruh Indonesia, termasuk di Kota Surakarta. Persaingan antar penyelenggara ibadah umrah memicu berbagai persoalan sebagaimana disebutkan di atas. Pada tahun 2017, di Kota Surakarta terdapat 4 PPIHU (Penyelenggara Perjalanan Ibadah Haji Umrah) yang berpusat di Surakarta dan 22 PPIHU Nasional yang membuka cabang di Solo (Purnomo, 2017). Seluruh PPIHU yang diumumkan oleh Kemenag Kota Surakarta merupakan PPIHU yang telah terdaftar dan terverifikasi oleh Kemenag. Verifikasi dilakukan untuk memastikan bahwa PPIHU benar-benar mampu mengelola dan menyelenggarakan perjalanan ibadah umrah sesuai standar tanpa merugikan jamaah.

Tetapi verifikasi saja tidak menjamin ketiadaan masalah. Berbagai masalah 
lain muncul dari sisi dan berkembang seiring dengan pesatnya pertumbuhan jumlah calon jamaah umrah. Untuk itu perlu dilakukan pemetaan terhadap berbagai persoalan yang muncul saat ini untuk dapat dianalisis faktor penyebabnya, sehingga dapat dirumuskan alternatif solusi untuk menyelesaikan berbagai permasalahan yang muncul dalam penyelenggaraan ibadah Umrah.

Kajian tentang haji dan umrah atau pun umrah secara khusus menarik perhatian pada akhir-akhir ini. Kajian tentang kebijakan haji dan umrah secara historis pernah dilakukan oleh Moch. Nur Ichwan. Dalam tulisannya, ia menyatakan bahwa kompleksitas masalah dalam pengelolaan haji dan umrah lebih banyak disebabkan oleh masalah yang bermotif politik dan ekonomi daripada aspek keagmaan itu sendiri (Ichwan, 2008). Sementara Soediyono Hidayat Purbaningrat (2012) menyoroti tentang tata kelola haji dalam "Komunikasi Transendental dalam Bisnis Travel Haji dan Umrah Di Indonesia" dengan fokus pada analisis komunikasi yang digunakan oleh PPIHU dalam proses penyelenggaraan ibadah umrah. Penelitian ini menyimpulkan bahwa Penyelenggaraan perjalanan haji akan berjalan baik apabila dikelola oleh lembaga yang kuat dan diusung oleh Sumber Daya Manusia yang jujur, amanah, bertanggung jawab, kompeten, dan berorientasi pada pemberian pelayanan dan perlindungan kepada jamaah. Hanya dengan cara itu jamaah haji Indonesia dapat terhindar dari permainan tangan-tangan yang tidak bertanggungjawab (Purbaningrat, 2012).

Pada sisi yang berbeda, penelitian Ridha (2014) mengungkapkan haji dan umrah di tengah pertumbuhan Economic Of Leisure. Artikel ini mendeskripsikan bahwa aktifitas berhaji dan umrah saat ini tak hanya didorong oleh tendensi perjalanan suci semata, namun sudah berubah menjadi komoditas yang diperdagangkan untuk mendapatkan keuntungan bagi perusahaan pengelola travel haji dan umrah terkait perkembangan dan pertumbuhan perjalanan wisata dunia (Ridha, 2014). Hal senada juga disampaikan oleh Sucipto yang melihat umrah telah bergeser dari makna awalnya dan menjadi salah satu komoditas industri (Sucipto, 2013).

Qi Mangku Bahjatulloh dari IAIN Salatiga pada tahun 2015 menulis tentang "Pengembangan Wakaf Tunai Berbasis Umrah Di Pondok Pesantren Ta'Mirul Islam Surakarta". Tulisa ini fokus pada kajian mengenai wakaf yang dikorelasikan dengan penyelenggaraan umrah di Pondok Pesantren Ta'mirul Islam Surakarta. Penelitian ini menyimpulkan bahwa wakaf tunai berbasis umrah adalah amal usaha untuk melayani jamaah dalam ibadah umrah dan haji serta wakaf tunai. Amal usaha ini menggabungkan model akad tijari dan aqad tabarru, yang praktiknya sesuai dengan syariah (Bahjatulloh, 2015).

Selaras dengan apa yang dijabarkan oleh Ridha, Hartini Thahir menulis tentang "Haji dan Umrah sebagai Gaya Hidup : Pertumbuhan Bisnis Perjalanan Suci di Kota Makasar". Artikel ini mengupas secara lugas tentang bagaimana praktik berangkat haji dan umrah tumbuh dan berkembang di Masyarakat 
Makassar. Dalam tulisannya ia menemukan bahwa praktik haji dan umrah terus tumbuh dan menjadi praktik yang meluas di masyarakat setidaknya sepuluh tahun terakhir ini. Kondisi pertumbuhan ekonomi yang cukup tinggi dan peningkatan apresiasi terhadap gaya hidup religius telah menjadi konteks yang mengkondisikan praktik ini lahir dan berkembang di Makassar (Thahir, 2016).

Dari beberapa kajian terdahulu terlihat bahwa penelitian yang dipublikasikan tentang permasalahan pengelolaan umrah masih sangat minim. Sebagian besar menyoroti umrah dalam konteks sosial beserta dampaknya di tengah masyarakat, belum fokus pada permasalahan apa yang muncul dalam proses penyelenggaraan umrah. Sehingga penelitian ini sangat penting untuk dilakukan sebagai analisis terhadap hal tersebut dan hasilnya dapat dijadikan pijakan bagi berbagai pihak untuk merumuskan solusi terhadap berbagai masalah yang muncul dalam penyelenggaraan ibadah umrah.

Artikel ini ditulis berdasarkan hasil penelitian kualitatif deskriptif dengan pendekatan studi kasus. Fokus utamanya adalah mengeksplorasi berbagai permasalahan yang muncul dalam penyelenggaraan ibadah umrah dari sisi penyelenggara maupun jamaah. Penggunaan pendekatan studi kasus diharapkan dapat memudahkan peneliti untuk mengeskplorasi masalah yang menjadi fokus penelitian ini. Proses eksplorasi fokus dimulai dengan brainstorming terhadap masalah umum penyelenggaraan umrah di Kota Surakarta. Kategorisasi dilakukan untuk menajamkan proses pendalaman masalah umum sehingga memudahkan peneliti dalam memilah data penelitian.

Sumber data dalam penelitian ini adalah pihak Kantor Kemenag Kota Surakarta, PERPUHI (Persaudaraan Pengusaha Travel Umrah Haji Indonesia), beberapa lembaga penyelenggara umrah (biro tour \& travel) di Kota Surakarta, jamaah umrah di Kota Surakarta. Penentuan sumber data menggunakan teknik snowball sampling, sedangkan key informan pada penelitian ini adalah pihak Kementerian Agama Kota Surakarta. Penelitian ini dilakukan dalam rentang waktu 4 bulan pada tahun 2017 di kota Surakarta.

\section{HASIL DAN PEMBAHASAN}

\section{Umrah bagi Umat Islam Indonesia}

Umrah menjadi sebuah perjalanan suci sehingga setiap apa yang kita lakukan di Tanah Suci dihitung sebagai pahala ibadah, bahkan ketika kita memberikan sedikit bantuan makan atau minum kepada teman seperjalanan yang sedang kesulitan atau kepada orang yang sedang membutuhkan bantuan yang kita temui di sana. Umrah bisa dikatakan sebagai haji kecil, bahkan bagi mereka yang merasa tidak sanggup menunggu terlalu lama untuk melaksanakan ibadah haji, umrah merupakan solusi yang lebih realistik. Hal ini memicu maraknya pelaksanaan umrah di Indonesia, tidak hanya bagi orang dewasa, namun juga remaja hingga anak-anak (Masitah, 2015). 
Pemerintah Arab Saudi melakukan pengurangan kuota haji Indonesia sebesar 20\% karena adanya proyek perluasan Masjdil Haram. Pemotongan kuota haji itu berlaku selama pengerjaan mega proyek itu berlangsung yang diperkirakan maksimal rampung dalam 3 tahun atau sekitar tahun 2016 (Republika, 2017). Proyek tersebut memicu jamaah calon haji beralih dari haji reguler menjadi haji plus yang lebih singkat masa tunggunya atau bahkan melakukan umrah yang tidak dibatasi oleh kuota secara ketat. Selain itu, perkembangan ekonomi Indonesia yang relatif stabil juga turut berkontribusi dalam meningkatkan jumlah kelas menengah Muslim yang prospektif menjadi jamaah umrah tiap tahunnya.

Peningkatan taraf ekonomi kelas menengah muslim memicu lonjakan perjalan ibadah umrah pada setiap tahunnya. Hal ini selaras dengan semakin mudahnya mendapatkan layanan perjalanan ibadah haji yang tersedia hampir di setiap kota dan kabupaten. Tidak hanya bagi masyarakat muslim kelas menengah, umrah mulai menjadi kebutuhan sekunder masyarakat muslim, bahkan pada kelas menengah ke bawah. Berbagai program umrah murah digagas oleh biro perjalanan umrah untuk menarik minat masyarakat kelas menengah ke bawah. Model arisan umrah dan kredit umrah merupakan program umrah yang mulai marak ditawarkan kepada masyarakat muslim. Ini mengindikasikan bahwa pangsa pasar usaha jasa perjalanan umrah semakin baik (Masitah, 2015).

Hartini Tahir dalam penelitiannya mengungkapkan perubahan motivasi jamaah haji dan umrah di Kota Makasar. Haji dan umrah tidak lagi hanya menjadi ritual semata namun menjadi bagian dari cara masyarakat kelas menengah untuk mengisi waktu luangnya dengan melaksanakan ibadah Umrah. Pergeseran motivasi ini pun selaras dengan perubahan pola pengelolaan biro travel penyelenggara ibadah umrah yang lebih mementingkan aspek kenyamanan seorang wisatawan daripada aspek spiritualitas seorang jamaah (Thahir, 2016).

\section{Regulasi Penyelenggaraan Umrah di Indonesia}

Pemerintah mengatur pelaksanaan ibadah umrah dalam undang-undang nomor 13 Tahun 2008 tentang Penyelenggaraan Ibadah Haji. Undang-undang ini kemudian dilengkapi dengan PP Nomor 79 Tahun 2012 yang mengatur tentang pelaksanaan undang-undang tersebut. Dalam PP tersebut disebutkan bahwa penyelenggaraan ibadah umrah dilakukan oleh pemerintah dan atau PPIU (Penyelenggara Perjalanan Ibadah Umrah) yang ditunjuk oleh pemerintah. Hal ini menegaskan bahwa siapapun yang ingin membentuk sebuah lembaga PPIU haruslah mendapat mandat dari pemerintah yang diwakili oleh Kementerian Agama pada Direktorat Penyelenggara Haji dan Umrah (PHU). Kewenangan ini hanya diberikan kepada Kemenag pusat, sedangkan Kemenag provinsi dan kabupaten hanya berhak untuk memberikan rekomendasi pendirian PPIU/PPIHU.

Beberapa tahun terakhir, umrah sudah menjadi kebutuhan yang primer akibat panjangnya waiting list ibadah haji. Di sisi lain, kenyataan ini ditangkap oleh 
para pelaku bisnis sebagai peluang untuk mendapatkan keuntungan ekonomis, dan sebagian lagi dengan alasan membantu masyarakat mewujudkan keinginan, sehingga mereka menjadi Penyelenggara Perjalanan Ibadah Haji Umrah (PPIHU). Persaingan di antara PPIHU ditambah dengan semakin banyaknya alternatif penerbangan dan hotel yang semakin variatif, dan juga kreativitas PPIHU dalam melahirkan produk. Hal itu juga didukung oleh adanya pergeseran makna kenyamanan terkait ibadah umrah.

Dahulu PPIHU mendefinisikan kenyamanan dengan fasilitas penerbangan, hotel, berbintang, dan pelayanan prima kepada jemaah. Namun saat ini, kenyamanan ibadah umrah itu didapatkan sebagian jemaah karena bisa melaksanakan umrah bersama ustad idolanya. Sebagian yang lain mendefiniskan kenyamanan dengan efisiensi, bukan lagi dengan fasilitas yang memadai. Namun PPIHU yang menyelenggarakan umrah dengan harga murah juga menguntungkan masyarakat. Masyarakat semakin banyak mendapatkan kesempatan menunaikan ibadah umrah dengan harga terjangkau. Fenomena umrah murah itu sudah sesuai dengan hak konsumen untuk mendapatkan harga yang kompetitif dan ekonomis. Apalagi tidak selamanya umrah murah itu pelayanannya buruk dan umrah mahal identik dengan pelayanan baik. Karena itu, penurunan harga akan terjadi ketika terdapat kompetitor yang saling berkompetisi menawarkan jasanya.

Namun demikian, pemerintah tidak menetapkan harga minimal umrah. Fokus pemerintah memperhatikan kualitas setiap PPIHU. Oleh sebab itu, berapa pun harga umrah, namun yang harus menjadi perhatian PPIHU adalah standar pelayanan minimal. Saat ini Kementerian Agama sedang merivisi standar pelayanan minimal (SPM) umrah yang terdapat dalam Peraturan Menteri Agama Nomor 18 Tahun 2015 tentang PPIHU (Kemenag, 2017). Dalam SPM yang sedang disusun Kemenag, travel penyelenggara umrah tidak boleh melakukan transit lebih dari satu kali dengan menggunakan satu maskapai. Selain itu, penyelenggara harus menyediakan hotel yang tidak lebih 1 kilometer dari Masjidil Haram dan Masjid Nabawi. Jika lebih dari 1 kilometer, maka penyelenggara diwajibkan menyediakan trasnportasi untuk jemaah. Hotel yang digunakan maksimal setiap kamar hanya boleh diisi 4 orang jemaah. Travel penyelenggara juga diwajibkan menyediakan konsumsi dalam bentuk prasmanan. Untuk pelayanan kesehatan, travel penyelenggara wajib menyediakan satu orang petugas kesehatan untuk 90 jemaah umrah.

\section{Perkembangan Penyelenggaran Umrah di Indonesia}

Perkembangan penyelenggaraan umrah di Indonesia tidak terlepas dari sejarah perkembangan penyelenggaraan ibadah Haji. Pada mulanya pelaksanaan umrah dilaksanakan menyatu dengan ibadah haji. Tren penyelenggaraan umrah secara terpisah dari ibadah haji baru berkembang pasca tahun 1980 saat pemerintah memberikan peluang pelaksanaan ibadah haji khusus yang kemudian dikenal dengan ONH Plus (Ichwan, 2008). 
Pihak swasta sendiri menyebut kegiatan itu merupakan sub-sistem atau bagian dari penyelenggaraan haji oleh pemerintah. Disebut subsistem karena otoritas mengenai ketentuan perusahaan mana saja, kuota, dan harga paket $\mathrm{ONH}$ Plus masih di tangan pemerintah hingga kini. Selain melibatkan perusahaan yang bergerak di bidang ONH Plus, pemerintah juga memberi kesempatan kepada berbagai yayasan, majelis ta'lim, ormas, milik masyarakat mengorganisir jamaah haji di lingkungannya. Kegiatan itu tidak lepas dari kontrol pemerintah dan tetap tergabung dalam paket penyelenggaraan urusan haji yang dikelola pemerintah.

Pihak swasta pengelola ONH Plus dalam perkembangannya tidak hanya menyelenggarakan ibadah haji saja namun mulai mengembangkan layanan perjalanan umrah di luar musim haji. Geliat perkembangan jumlah jamaah umrah di luar musim haji mulai meningkat pada tahun 2004, saat terjadi saat 30.000 calon jamaah haji gagal berangkat karena pemerintah Saudi Arabia menolak penambahan kuota jamaah haji (Erianto, 2015). Insiden ini kemudian mulai memicu maraknya perjalanan umrah di luar musim haji. Calon jamaah haji yang gagal berangkat memilih untuk melaksanakan umrah di luar musim haji.

Pada tahun 2012, Pemerintah Arab Saudi menentukan kuota bagi jemaah haji Indonesia sebesar 192.291 orang. Namun sejak tahun 2013 kuota tersebut berkurang hingga 20\%. Jumlah jemaah haji Indonesia dibatasi menjadi tidak lebih dari 155.000 orang saja (BPS, 2017). Pengurangan tersebut terjadi akibat proyek perluasan Masjidil Haram.

Berdasarkan ketentuan tersebut, kemudian pemerintah menetapkan kuota haji reguler, kuota haji khusus, dan kuota provinsi dengan memerhatikan prinsip keadilan dan proporsional. Kuota haji provinsi kemudian disampaikan kepada gubernur masing-masing daerah. Kemudian gubernur menentukan kuota haji untuk setiap kota dan kabupaten di wilayahnya masing-masing. Dalam menentukan porsi kuota bagi tiap provinsi, pemerintah mengacu pada data sensus penduduk BPS yang dimutakhirkan setiap 10 tahun sekali. Dengan mengetahui data tentang jumlah penduduk muslim dan kemampuan ekonomi tiap penduduk, pemerintah dapat menentukan porsi kuota bagi 34 provinsi di Indonesia (BPS, 2017).

Namun masalah baru muncul terkait dengan pemberlakuan sistem kuota. Terjadi antrean panjang para pendaftar haji yang telah memenuhi syarat namun tidak dapat diberangkatkan, akibat kuota tahunan telah terpenuhi. Membludaknya calon jemaah pendaftar, tidak sebanding dengan kuota yang diperoleh. Beberapa provinsi bahkan memiliki ribuan jemaah mengendap dalam daftar tunggu, dengan waktu tunggu yang tidak tanggung-tanggung, yakni antara 15 hingga 20 tahun (Muslimin, Wawancara, 22/08/2017). Ini adalah tantangan baru yang dihadapi pemerintah terkait penyelenggaraan haji.

Lamanya waktu tunggu ini tentu saja membuat bisnis penyelenggaraan umrah semakin berkembang. Berdasarkan informasi dari statistik Kementerian Agama sejak tahun 2015 jumlah jamaah umrah yang berasal dari Indonesia 
meningkat signifikan rata-rata 7,2 persen setiap tahunnya. Berdasarkan data visa umrah yang dikeluarkan oleh Pemerintah Arab Saudi, pada tahun 2016 Indonesia menempat urutan ketiga sebagai pengirim jamaah umrah terbesar setelah Pakistan di urutan ke dua dan Mesir sebagai pengirim jamaah umrah terbanyak sebesar 1,3 juta orang pertahun (PHU Kemenag, 2017a).

Peningkatan jumlah jamaah umrah selaras dengan meningkatnya jumlah biro travel penyelenggara umrah. Menurut statistik kementerian agama pada tahun 2015-2016 tercatat 651 PPIHU (Penyelenggara Perjalanan Ibadah Haji Umrah) dengan total jamaah umrah sebanyak 649.000 jamaah. Jumlah ini meningkat pada tahun 2016-2017 menjadi 830 PPIHU dengan jumlah jamaah sebanyak 699.000 orang. Berdasarkan data tersebut, bila pada tahun 2015 jumlah jemaah dibagi rata ke setiap PPIHU, masing-masing mendapatkan paling tidak seribu calon jemaah umrah. Tapi pada 2016, bila dirata-rata, setiap agen travel mendapat 820-an calon jemaah. Tapi, tentu kenyataannya tidak demikian. Karena bisa saja beberapa PPIHU mendapat lebih banyak dari angka rata-rata tersebut, sementara PPIHU justru mengalami penurunan hingga jauh di bawah angka rata-rata tersebut (PHU Kemenag, 2017b).

Kondisi demikian tentu merangsang agen umrah untuk bisa mempertahankan jumlah calon jemaahnya, malah kalau bisa ditingkatkan. Jangan sampai menurun. Berbagai instrumen pemasaran muncul, mulai dari pola pembayaran cicilan laiknya ongkos haji hingga model Multi Level Marketing (MLM) yang disebut-sebut mirip skema ponzi. Tujuannya satu, harga bisa terasa ringan di kantong calon jemaah, lantas jasa biro perjalanannya laku keras. Dengan memanfaatkan maraknya kasus-kasus penipuan umrah, beberapa diantara mereka yang tak mampu bersaing harga, mendompleng kampanye Kemenag soal kehatihatian memilih agen umrah. Bahkan sebelumnya, empat asosiasi penyelenggara umrah bersepakat menerapkan standar minimal biaya umrah, yakni USD \$ 1700 atau saat ini sekitar Rp 22 juta. Mereka adalah Asosiasi Muslim Penyelenggara Haji dan Umrah Republik Indonesia (Amphuri), Himpunan Penyelenggara Umrah dan Haji (Himpuh), Asosiasi Penyelenggara Haji Umrah dan Inbound Indonesia (Asphurindo), dan Kesatuan Tour Travel Haji dan Umrah Republik Indonesia (Kesthuri). Dengan adanya aturan main di kalangan asosiasi ini, travel manapun yang menerapkan harga murah patut dicurigai memakai skema ponzi, artinya berpotensi merugikan calon jemaah umrah (Lubis, 2017).

Model-model pembiayaan yang semakin beragam pada satu sisi menguntungkan calon jamaah, terutama yang berasal dari kalangan ekonomi menengah ke bawah. Namun, pada sisi yang lain calon jamaah juga rentan menjadi korban penyelewengan dana oleh biro travel. Dalam kasus ini peran Kementerian Agama sebagai regulator diharapkan mampu menjadi pengontrol pelaksanaan penyelenggaraan umrah, menjamin calon jamaah tidak dirugikan oleh biro travel.

\section{Penyelenggaraan Umrah di Kota Surakarta}


Kota Surakarta memiliki kepadatan penduduk dalam kategori sedang. Jumlah penduduk kota Surakarta pada tahun 2016 sebanyak 585.486 Orang dengan total penduduk muslim sekitar 408.231 Orang atau sekitar $69.7 \%$ dari total penduduknya. Berdasarkan rasio jamaah haji 1:1000 maka pada tahun 2017 jumlah jamaah haji Kota Surakarta sebanyak 619 Orang, jumlah tersebut sudah termasuk penambahan kuota sebanyak 211 orang. Jumlah ini tidak sebanding dengan jumlah calon jamaah haji yang semakin banyak sehingga masa masa tunggu calon jamaah haji Kota Surakarta saat ini adalah 20 tahun (Muslimin, Wawancara, 22/08/2017).

Rentang waktu masa tunggu hingga keberangkatan semakin jauh saat jumlah pendaftar calon jamaah haji semakin banyak sementara kuota jamaah haji yang diberikan pada setiap tahun tidak bertambah. Kondisi ini memicu peralihan orientasi sebagian calon jamaah haji ke arah pelaksanaan umrah yang lebih fleksibel waktu pelaksanaannya. Melaksanakan umrah menjadi alternatif bagi mereka yang tidak sabar dengan lamanya masa tunggu sebagai calon jamaah haji, terutama bagi jamaah yang merasa usianya cukup lanjut atau karena faktor lain seperti kesehatan yang tidak memungkinkan (Masitah, 2015).

Penyelenggaraan pelayanan perjalanan umrah di kota Surakarta melibatkan dua pihak yang saling terkait. Kementerian Agama sebagai regulator dan Biro Travel sebagai pelaksana penyelenggaraan perjalanan umrah. Keberadaan kedua pihak ini sebenarnya telah diatur oleh undang-undang nomor 13 tahun 2008 Tentang penyelenggaraan ibadah haji dan umrah. Namun dalam pelaksanaannya, undang-undang tersebut hanya mengatur secara jelas tentang pelaksanaan perjalanan ibadah haji yang menjadi tanggung jawab Kementerian Agama dari tingkat kabupaten hingga pusat. Sedangkan untuk penyelenggaraan perjalanan ibadah umrah walaupun sudah diatur menjadi satu kesatuan dengan haji dalam UU tersebut namun dalam pelaksanaannya diserahkan kepada pihak swasta kemudian dikenal dengan istilah Penyelenggara Perjalanan Ibadah Haji Umrah (PPIHU) (Muslimin, Wawancara, 22/08/2017).

PPIHU yang menyelenggarakan ibadah umrah di kota surakarta sejumlah 26 PPIHU. Dari jumlah tersebut 4 PPIHU berasal dari kota Surakarta dan 22 PPIHU merupakan cabang dari PPIHU yang berkantor pusat di daerah lain. Sebagian besar berkantor pusat di Jakarta dan Semarang serta Surabaya. Tidak terdapat perbedaan yang mencolok antara PPIHU yang berasal dari kota Surakarta dengan yang berkantor pusat di daerah lain. Perbedaannya hanya pada pola pemberangkatan jamaah. Bagi PPIHU yang berasal dari Surakarta pemberangkatan jamaah langsung dilakukan lewat Bandara Adi Sumarmo Boyolali, sedangkan PPIHU cabang biasanya memberangkatkan jamaahnya dari kota asalnya seperti Jakarta, Semarang atau Surabaya. Namun sejak awal tahun 2017, beberapa PPIHU cabang pun mulai memberangkatkan jamaahnya dari Bandara Adi Sumarmo setelah terjalin kerjasama antara PERPUHI (Persaudaraan Pengusaha Haji Umrah Indonesia) dengan maskapai Garuda Indonesia. 
Kerjasama ini memungkinkan PPIHU di wilayah Solo Raya yang tergabung dalam PERPUHI untuk mendapatkan potongan harga tiket penerbangan dari Bandara Adi Sumarmo Boyolali ke Jeddah pada periode tertentu.

Keberadaan PERPUHI yang berdiri pada 03 Februari 2017 pada awalnya hanya sebagai wadah untuk menaungi PPIHU agar dapat menjalin kerjasama dengan pihak Garuda Indonesia. Dalam pekembangannya PERPUHI tidak hanya sekedar menaungi PPIHU saja namun diarahkan menjadi fasilitator koordinatif PPIHU. Keberadaan PERPUHI sebagai organisasi asosiasi PPIHU cukup membantu proses pengelolaan penyelenggaraan ibadah umrah, terutama sebagai pembantu Kementerian Agama dalam menstandarisasi pengelolaan pada tingkat PPIHU (Azwar, Wawancara, 20/08/2017).

Standarisasi pelayanan PPIHU terhadap jamaah diharapkan dapat meminimalisir hal-hal yang dapat merugikan yang terlibat dalam penyelenggaraan ibadah umrah, khususnya calon jamaah umrah. Namun standarisasi yang dibuat oleh PERPUHI pun tidaklah mengikat karena sifatnya hanya himbauan. Tidak ada sangsi yang diberlakukan bagi PPIHU yang terbukti tidak mengikuti standarisasi PERPUHI. PPIHU yang tidak mengikuti standar hanya diberi teguran secara lisan atau hanya dikeluarkan dari keanggotaan PERPUHI jika pelanggarannya tergolong berat. Namun hal ini hanya berlaku bagi PPIHU yang menjadi anggota PERPUHI, sedangkan bagi PPIHU yang tidak menjadi anggota tentu tidak menjadi kewenangan PERPUHI untuk menegur ataupun memberi sangsi (Azwar, Wawancara, 20/08/2017).

Berdasarkan standar yang dibuat oleh PERPUHI, PPIHU menerima pendaftaran calon jamaah berdasarkan periode keberangkatan yang telah direncanakan. Namun dalam proses pemilihan periode keberangkatan ini, PPIHU harus menjelaskan kepada calon jamaah bahwa periode tersebut bersifat tentatif, sangat tergantung pada banyak hal, diantaranya adalah penerbitan visa umrah dari KSA, ketersediaan tiket dari maskapai Garuda dan faktor lain yang tidak dapat diprediksi seperti ketersediaan akomodasi di Mekkah. Setelah memilih periode keberangkatan maka jamaah sudah diperbolehkan untuk membayar ongkos perjalanan namun dalam jumlah yang tidak melebihi $75 \%$ total biaya. Hal ini untuk menghindari praktik manipulatif pihak PPIHU. Pembayaran ini digunakan oleh PPIHU untuk melakukan pengurusan visa, booking tiket serta akomodasi hotel di Mekkah. "Jika ada PPIHU yang meminta pembayaran secara penuh pada awal pendaftaran maka hal tersebut patut dicurigai sebagai indikasi praktik penipuan, walaupun tidak selalu begitu. Tapi dari standar kami pembayaran dilakukan secara bertahap" jelas Azwar, Sekjen PERPUHI (Wawancara, 20/08/2017).

Menjelang keberangkatan calon jamaah akan diminta untuk melunasi seluruh pembiayaan, termasuk penambahan biaya jika terdapat perubahan yang disebabkan oleh hal tak terduga seperti perubahan harga akomodasi karena kenaikan kurs mata uang Rupiah terhadap Riyal. Pada tahapan ini selain melunasi pembayaran calon jamaah juga akan mendapatkan bimbingan manasik antara 1-3 
kali. Setelah mendapat bimbingan manasik maka calon jamaah umrah sudah dapat mempersiapkan diri untuk keberangkatan yang biasanya dilakukan sekitar 1 hingga 2 minggu setelah kegiatan manasik umrah.

Alur penyelenggaraan ibadah umrah tersebut merupakan standar yang disepakati oleh PPIHU dan ditetapkan oleh PERPUHI sebagai asosiasi yang menaungi PPIHU di kota Surkarta. Namun standar tersebut tentu tidak mengikat dan bisa saja tidak diikuti apalagi oleh PPIHU yang tidak menjadi anggota PERPUHI. Seksi PHU Kementerian Agama sendiri tidak memiliki standarisasi proses penyelenggaraan ibadah umrah karena keterbatasan kewenangan yang diberikan oleh peraturan yang berlaku."kami hanya bisa melakukan pendataan mas, untuk masalah proses penyelenggaraan sudah masuk wilayah internal biro travel. Jika ada laporan dari masyarakat, kami catat dan kami teruskan kepada kemenag propinsi. Lalu jika ada masyarakat yang tanya-tanya baru kami beritahu mana saja biro travel yang bisa dipercaya." kata Anis, Staf Kemenag Kota Surakarta (Wawancara, 24/08/2017).

Menyikapi PPIHU yang terbukti merugikan calon jamaah umrah, Kementerian Agama Kota Surakarta melalui Seksi Penyelenggaraan Haji-Umrah (PHU) sebagai regulator penyelenggaraan ibadah Umrah tidak dapat melakukan penindakan karena kewenangannya sangat terbatas pada pemberian rekomendasi kepada Kementerian Agama Kantor Wilayah Semarang untuk diteruskan kepada Kementerian Agama Pusat. Selain memberikan rekomendasi dalam proses penerbitan ijin bagi PPIHU di wilayahnya, Seksi PHU Kementerian Agama Kota Surakarta juga memberikan rekomendasi kepada calon jamaah umrah yang akan mengurus paspor. Namun rekomendasi tersebut bukanlah syarat mutlak karena dalam aturan keimigrasian rekomendasi dari Kementerian Agama bukanlah syarat yang utama untuk penerbitan paspor. Hal ini terlihat dari beberapa PPIHU langsung mengurus paspor calon jamaahnya ke kantor keimigrasian tanpa rekomendasi dari seksi PHU Kementerian Agama.

\section{Kementerian Agama Kota/Kabupaten : Regulator Umrah tanpa Kewenangan}

Kementerian Agama dalam kegiatan penyelenggaraan ibadah haji dan umrah secara khusus membentuk seksi Penyelenggara Haji Umrah (PHU) sebagai pengelola kegiatan pada satu sisi dan sebagai regulator pada sisi yang lain. Dalam penyelenggaraan ibadah haji reguler, PHU Kemenag mendapat kewenangan mutlak oleh undang-undang kecuali pada penyelenggaraan ibadah haji khusus yang diberikan kepada Biro Travel. Namun untuk dapat menjadi penyelenggara ibadah haji khusus sebuah Biro Travel harus melalui pengujian yang ketat dan pengawasan langsung dari PHU.

Berbeda dengan penyelenggaraan ibadah umrah, PHU Kemenag hanya sebagai regulator dengan kewenangan yang sangat terbatas pada pendataan dan pemberian rekomendasi bagi PPIHU dan calon jamaah sebagaimana dijelaskan 
sebelumnya. Pada tingkat Kemenag Pusat ada kewenangan untuk memberikan ijin penyelenggaraan serta pencabutan ijin jika terbukti merugikan jamaah umrah. Namun pada tingkat Kemenag Kota dan Kabupaten seperti di Kota Surakarta kewenangannya sangat terbatas pada pendataan dan pemberian rekomendasi, jelas Muslim Umar, Kepala Kantor Kemenag Kota Surakarta (Wawancara, 21/08/2017)

Keterbatasan kewenangan ini juga terlihat dari belum tersedianya sistem pendataan bagi calon jamaah umrah di PHU Kemenag. Jika pendaftaran haji terpusat pada SISKOHAT maka untuk pendataan jamaah umrah belum ada sistem yang dibuat. Bahkan data manual dalam bentuk tabulasi data di komputer belum tersedia. Ketiadaan data ini disebabkan beberapa hal, diantaranya adalah keterbatasan SDM di Seksi PHU, tidak ada regulasi yang mengharuskan calon jamaah mendaftarkan dirinya ke Seksi PHU Kemenag Kota/Kabupaten baik secara pribadi maupun dikoordinasi oleh PPIHU, belum tersedia sistem yang digunakan untuk melakukan pendataan. Padahal keberadaan data calon jamaah dapat membantu Seksi PHU Kemenag dalam melakukan analisa terhadap perkembangan pengelolaan penyelenggaraan ibadah umrah di wilayahnya.

Tidak hanya data jamaah saja, data PPIHU pun tidak sepenuhnya valid karena tidak ada kewajiban bagi PPIHU untuk melaporkan keberadaan dan kegiatannya kepada seksi PHU Kemenag. Data yang dimiliki Seksi PHU Kemenag tentang jumlah PPIHU di wilayah Kota Surakarta adalah data yang berasal dari kegiatan pemantauan spanduk, baliho dan media promo yang menyebutkan alamat Biro Travel penyelenggara umrah. Berdasarkan data tersebut Seksi PHU Kemenag melakukan visitasi ke wilayah tersebut, jika ternyata sesuai dengan informasi yang didapat maka Biro Travel tersebut dinyatakan valid. Namun jika ada PPIHU yang tidak memasang papan nama, spanduk ataupun media promo tentu tidak akan terdata oleh Seksi PHU Kemenag.

Proses verifikasi terhadap PPIHU dilakukan secara insidentil, tidak terprogram secara berkala. Pendataan dilakukan berdasarkan instruksi dari Kemenag tingkat Provinsi Jawa Tengah. Untuk melakukan pendataan ini Seksi PHU Kemenag dibantu oleh Satpol PP Kota Surakarta sebagai pihak yang lebih berkompeten dalam penerbitan atribut media promo di Kota Surakarta. Berdasarkan pendataan terdapat 26 PPIHU di wilayah Kemenag Kota Surakarta. 4 PPIHU berasal dari Kota Surakarta sedangkan 22 lainnya merupakan cabang PPIHU dari wilayah lain, baik dari sekitar Kota Surakarta maupun luar provinsi Jawa Tengah seperti Surabaya, Yogyakarta maupun Jakarta.

Kemampuan Seksi PHU Kemenag Kota Surakarta dalam melakukan pendataan kegiatan pengelolaan dan penyelenggaraan ibadah umrah terbatasi juga oleh jumlah SDM yang ada. Seksi PHU Kemenag Kota Surakarta dipimpin oleh Kepala Seksi dibantu dua orang staf PNS dan satu honorer. Setiap hari 2 orang staf harus melakukan pelayanan publik dalam pendaftaran calon jamaah haji menggunakan SISKOHAT. Sementara satu staf lagi sebagai admin perkantoran. 
Dengan formasi yang tersedia maka SDM untuk melakukan pengelolaan data umrah tentu tidak memadai.

\section{Biro Travel : Legalitas sebagai PPIHU hingga Persaingan Bisnis}

Biro Travel sebagai Penyelenggara Perjalanan Ibadah Haji Umrah (PPIHU) merupakan pihak yang paling dominan dalam proses penyelenggaraan perjalanan ibadah umrah para jamaah. Oleh karena itu kemampuan PPIHU dalam mengelola proses penyelenggaraan ibadah umrah sangat menentukan kenyamanan jamaah dalam melaksanakan ibadah umrah. Namun proses standarisasi kualitas layanan bagi sebuah PPIHU masih sulit untuk dilakukan, apalagi saat ini kontrol terhadap PPIHU masih sangat longgar. Beberapa PPIHU belum memiliki izin secara resmi untuk menjadi Penyelenggara Perjalanan Ibadah Haji Umrah. Mereka hanya biro travel umum yang kemudian membuka program perjalanan umrah, baik diselenggarakan sendiri maupun bekerjasama dengan biro travel lain yang telah menjadi PPIHU. Untuk dapat menjadi PPIHU secara resmi sebuah biro travel harus mengajukan permohonan kepada Kementerian Agama Pusat melalui Direktur Jendral Penyelenggaran Haji dan Umrah. Permohonan tersebut disertai dengan dokumen berupa Surat rekomendasi dari Kepala Kantor Wilayah Kementerian Agama Provinsi, Salinan izin usaha perusahaan yang dilegalisasi Dinas Pariwisata Provinsi atau Pemerintah Daerah setempat, Susunan Organisasi Penyelenggara, Surat keterangan domisili, Menyerahkan uang jaminan sebesar Rp. 100.000.000,00 atau garansi dari salah satu bank Pemerintah.

Dokumen-dokumen tersebut harus melalui verifikasi baik pada tingkat Kementerian Agama Kota/Kabupaten dan Kementerian Agama Wilayah sebelum diajukan kepada Kementerian Agama Pusat. Proses pengurusan ijin PPIHU memerlukan waktu antara 3 sampai 5 bulan sejak pengajuan dari Kemenag Tingkat Kota/Kabupaten hingga terbitnya ijin secara resmi dari Kementerian Agama Pusat. Prosedur pengajuan izin tersebut sesuai dengan Keputusan Menteri Agama Republik Indonesia Nomor 396 Tahun 2003, Keputusan Direktur Jenderal Bimbingan Masyarakat Islam dan Penyelenggaraan Haji Nomor D/348 Tahun 2003, dan Peraturan Pemerintah Republik Indonesia Nomor 79 Tahun 2012. (PHU Kemenag, 2017b)

Proses perijinan yang cukup panjang dan lama menjadi salah satu faktor penyebab tidak semua PPIHU di Kota Surakarta memiliki ijin penyelenggaraan ibadah umrah. Beberapa Biro Travel yang tidak memiliki ijin memilih untuk melakukan proses pemberangkatan jamaah bersama dengan PPIHU yang telah memiliki ijin. Sedangkan yang lain memilih menjadi agen bagi PPIHU lain, hanya menerima pendaftaran calon jamaah, sedangkan proses pembimbingan, pemberangkatan hingga pendampingan jamaah selama melakukan ibadah Umrah dilakukan oleh PPIHU.

Proses pemberangkatan jamaah oleh sebuah PPIHU juga bisa dilakukan dengan proses merger dengan PPIHU lain disebabkan karena kuota jamaah yang 
tidak mencukupi. Dalam kasus seperti ini, PPIHU dengan jamaah lebih sedikit menitipkan jamaahnya kepada PPIHU lain dengan perjanjian yang sudah disepakati sebelumnya. Selain karena jumlah kuota jamaah yang tidak mencukupi, merger juga sering terjadi karena sebuah PPIHU memiliki sisa kursi pesawat. Kejadiannya ini dipicu oleh beberapa jamaah yang mengundurkan diri disebabkan oleh berbagai faktor. Sisa kursi pesawat yang kosong tersebut kemudian ditawarkan kepada PPIHU lain yang telah bekerjasama. Proses merger jamaah ini rentan menimbulkan masalah karena masing-masing PPIHU memiliki standar pelayanan yang berbeda, selain juga standar pembiayaan yang berbeda.

Tidak semua PPIHU memiliki standar pelayanan dan operasional yang sama. Beberapa mengutamakan kuantitas jamaah dengan menerapkan harga serendah mungkin, padahal harga yang rendah pasti berdampak pada kualitas layanan yang diberikan kepada jamaah. Untuk dapat menekan harga serendah mungkin, PPIHU umumnya menggunakan promo tiket pesawat yang tersedia pada waktu-waktu tertentu. Padahal jumlahnya sangat terbatas dan hal ini sering memicu ketidakpastian waktu pemberangkatan calon jamaah umrah. "sebenarnya kita sudah menjadwal pemberangkatan pada setiap periode, hanya saja kadang kita tidak kebagian tiket mas, jadi mau tidak mau mundur. Kita memang prioritas menggunakan tiket promo, karena harga yang kita tawarkan minimal sekali. Kalau tidak menggunakan tiket promo ya ndak nyandak harganya mas." Kata Farid, Managing Director PT. Amir Aliya Amalia (wawancara, 27/08/2017).

Ketidakpastian waktu pemberangkatan calon jamaah umrah merupakan masalah yang hampir dialami oleh semua PPIHU di Kota Surakarta. Untuk dapat memberangkatkan calon jamaah umrah, sebuah PPIHU harus mengumpulkan paling sedikitnya 40 orang calon jamaah umrah. Namun jumlah tersebut juga tidak menjamin keberangkatan bisa ditentukan, persoalan penerbitan visa oleh KSA juga menjadi penentu. Jika 40 visa dapat terbit secara bersamaan tidak menjadi masalah, namun jika beberapa orang tidak dapat diterbitkan secara bersamaan tentu hal tersebut akan memicu keterlambatan pemberangkatan karena PPIHU harus mengurus kembali calon jamaah yang visanya tidak diterbitkan oleh KSA. Sebagaimana disampaikan oleh Muhammad Iqbal, Manajer Operasional Kharisma Haramain Indonesia (Wawancara, 26/08/2017)

Masalah visa kadang tidak dipahami oleh jamaah mas, kadang kita sudah menguruskan trus nggak terbit karena macam-macam alasannya. Tapi yang jelas kalau ada yang tidak terbit visanya, kami yang pusing. Pertama jadwal sangat mungkin diundur, trus kami harus mengurus lagi dan biasanya jamaah nggak mau bayar lagi. Karena mereka merasa sudah membayar. Padahal uang yang kita gunakan untuk mendaftar visa tidak dikembalikan lagi jika ternyata visanya tidak keluar. Repot juga jadinya. Di situ kami kadang harus menjelaskan lagi kepada jamaah, tidak hanya kepada yang visanya tidak terbit, tapi juga kepada jamaah lain karena biasanya urusan visa ini menjadi salah satu penyebab kemunduran jadwal pemberangkatan. 
Tingginya minat umat Islam dalam menjalankan ibadah umrah memicu persaingan antar PPIHU dalam mencari calon jamaah. Promo harga murah masih menjadi cara utama PPIHU dalam menarik calon jamaah umrah. Padahal seringkali promo tersebut menjebak karena informasi yang tidak utuh. Ada PPIHU yang menetapkan harga lebih murah karena tidak memasukkan ongkos pengurusan visa dan paspor ke dalam paket harga. Ada juga PPIHU yang menetapkan harga murah namun dengan catatan bahwa harga tersebut masih dapat berubah sesuai dengan harga tiket perjalanan yang dihitung berdasarkan kurs dolar. Model-model promo murah seperti ini dapat memicu protes calon jamaah karena merasa ditipu oleh PPIHU.

Selain promo harga murah, terdapat beberapa model lain yang digunakan oleh PPIHU untuk mendapatkan calon jamaah sebanyak-banyaknya. Diantaranya adalah dengan mengadakan arisan umrah. Arisan umrah dapat dikelola langsung oleh calon jamaah sendiri ataupun dikoordinir oleh PPIHU. Jika dikelola oleh PPIHU berpotensi memunculkan penyelewenangan dana yang terkumpul. Demikian pula dengan pola kredit umrah dimana jamaah menyetorkan sejumlah uang secara bertahap dalam rentang waktu antara 2 hingga 3 tahun.

Macam-macam lah mas cara biro travel itu untuk menggaet sebanyak mungkin jamaah. Bisa pakai model arisan ada juga yang kredit. Ada juga yang menggunakan model MLM. Maka kami di PERPUHI tidak menyarankan anggota untuk menggunakan praktik-praktik seperti ini, kecuali memang bekerjasama dengan pihak bank secara langsung. Tapi sebenarnya jika dikelola dengan baik, model-model tersebut tidak menjadi masalah. Yang menimbulkan masalah biasanya jika uang yang disetor oleh jamaah tersebut digunakan oleh biro travel untuk investasi, seperti yang kasus first travel itu kan selain menggunakan model yang tidak lazim saya dengan mereka juga investasi ke Koperasi Pandawa yang bermasalah itu, nah ketika investasinya bermasalah jadi kena masalah juga biro travelnya (Muhammad Iqbal, Wawancara, 26/08/2017).

Dana yang disetorkan tersebut baik secara langsung kepada PPIHU ataupun rekening bank yang dimiliki oleh PPIHU berpotensi digunakan oleh PPIHU untuk kepentingan lain seperti investasi pada usaha tertentu dengan asumsi bahwa investasi dapat meningkatkan nilai dan keuntungan PPIHU. Praktik-praktik ini dilakukan oleh PPIHU dipicu oleh minimnya margin keuntungan dalam bisnis perjalanan umrah, terutama bagi PPIHU yang menerapkan harga promo semurahmurahnya. Masalah kemudian muncul ketika investasi yang digunakan oleh PPIHU ternyata tidak menghasilkan keuntungan dan dana jamaah tidak dapat kembalikan. Ini terjadi pada An-Nahl Umrah dan Hannien Tour yang saat ini sudah tidak dapat menjalankan kegiatan operasionalnya karena menyelewengkan dana yang disetorkan oleh calon jamaahnya.

Namun tidak semua PPIHU melakukan praktik investasi dana calon jamaah untuk mendapatkan margin keuntungan, beberapa PPIHU dengan segmentasi 
kelas menengah ke atas menerapkan harga yang cukup tinggi sehingga margin keuntungannya cukup besar. Harga yang lebih tinggi tentu harus disertai dengan pelayanan yang lebih dan tambahan destinasi, tujuan perjalanan umrah tidak hanya Mekkah dan Madinah namun ditambahkan dengan beberapa destinasi yang masih dalam jalur perjalanan Indonesia - Saudi Arabia seperti Turki, Dubai, Qatar dan bahkan ke Masjidil Aqsa Palestina.

Margin keuntungan bukanlah masalah bagi PPIHU dengan segmentasi masyarakat kelas menengah keatas, sedangkan bagi PPIHU bersegmentasi masyarakat menengah ke bawah selain menggunakan promo harga murah untuk mendapatkan sebanyak mungkin calon jamaah, margin keuntungan didapatkan dengan meminimalisir jumlah SDM yang digunakan dalam proses penyelenggaraan ibadah umrah. Jumlah SDM yang tidak memadai tentu berimbas pada kualitas pelayanan para jamaah selama perjalanan umrah hingga kembali. Selain meminimalisir SDM, PPIHU juga mengurangi kegiatan bimbingan manasik dari 3 kali kegiatan menjadi 1 kegiatan untuk mengurangi biaya operasional. Padahal hal ini berdampak bagi minimnya pemahaman calon jamaah terhadap proses pelaksanaan ibadah umrah. Karena dalam bimbingan manasik tersebut, pembimbing tidak hanya menyampaikan tentang teknis pelaksanaan ibadah umrah namun juga mengenai proses perjalanan yang akan dilalui oleh calon jamaah. Hal ini tentu menyebabkan konsentasi calon jamaah terhadap materi bimbingan manasik terpecah pada hal-hal teknis yang harus mereka siapkan menjelang keberangkatan ke tanah suci Mekkah.

Praktik-praktik tersebut dilakukan semata untuk meminimalisir biaya operasional sehingga margin keuntungan yang diperoleh PPIHU mencukupi. Padahal hal tersebut berpotensi memunculkan berbagai masalah bagi jamaah dalam pelaksanaan umrah nantinya. Hal ini disadari atau tidak merupakan tanggungjawab PPIHU sebagai pihak yang ditunjuk oleh Undang-undang untuk melakukan pelayanan kepada masyarakat. Namun hal ini tidak dipahami oleh semua PPIHU, baik oleh SDM teknis maupun pemilik PPIHU sendiri. Terutama bagi PPIHU yang masih belum miliki ijin resmi dari Kemenag. Padahal pemahaman tentang regulasi baik undang-undang maupun peraturan pemerintah yang menjadi turunannya merupakan dasar dari pelaksanaan penyelenggaraan ibadah umrah yang sesuai dengan standar pemerintah. Dengan mengikuti regulasi yang ada pemerintah berharap praktik-praktik yang merugikan jamaah umrah dapat diminimalisir.

\section{Problematika Pengelolaan Penyelenggaraan Umrah di Kota Surakarta : dari Regulasi hingga Persaingan antar PPIHU}

Umrah merupakan ibadah sunnah bagi umat Islam. Umrah tidak termasuk dalam ibadah wajib namun nabi sangat menganjurkan bagi umat Islam yang mampu untuk melakukan umrah minimal satu kali dalam hidupnya. Perbedaan antara umrah dengan haji hanya terletak pada pelaksanaan mabit di Mina, wukuf di Arafah 
dan melempar jumrah. Sedangkan pada tawaf dan sai sama dengan pelaksanaan dalam ibadah haji. Oleh karenanya umrah dianggap sebagai haji kecil. Namun umrah dapat dilakukan kapan saja tidak terikat waktu sebagaimana ibadah haji. Karena keterbatasan waktu pelaksanaanya maka pelaksanaan haji diatur secara ketat oleh pemerintah KSA (Kingdom Saudi Arabia) sebagai khadimul haramain. Pembatasan tersebut menyebabkan tidak semua umat Islam dapat berhaji pada waktu yang diinginkannya. Ada waktu tunggu yang diberlakukan oleh kementerian Agama selaku pengelola penyelenggaraan ibadah haji di Indonesia.

Lama waktu tunggu pelaksanaan ibadah Haji saat ini dipengaruhi oleh jumlah pendaftar dibandingkan dengan kuota yang diberikan pada setiap kabupaten/kota. Masing-masing daerah memiliki waktu tunggu yang berbeda antara satu dengan yang lain. Fenomena ini memicu meningkatnya minat masyarakat melaksanakan ibadah umrah sebagai alternatif untuk berkunjung ke Baitullah. Di beberapa daerah umrah disejajarkan dengan ibadah haji, bahkan mereka yang datang dari ibadah umrah disambut dengan cara yang sama dengan peyambutan terhadap jamaah haji.

Animo masyarakat dalam menunaikan ibadah umrah tidak hanya dipicu oleh lamanya waktu tunggu pelaksanaan haji, namun juga dipicu oleh simbolisasi haji dan umrah sebagai salah satu barometer kesalehan seseorang. Dengan melaksanakan umrah seorang muslim secara sosial mendapatkan prestis ganda, prestis religiusitas dan prestis sosial. Secara religiusitas dia dianggap sebagai orang yang pernah berkunjung dan beribadah di Masjidil Haram, padahal dalam keyakinan umat Islam satu kali beribadah di Masjidil Haram memiliki kutamaan 100.000 lebih baik dari pada ditempat lain (Azwar, 2007). Sehingga secara logis semakin sering seseorang melakukan umrah maka semakin tinggi pula derajat keutamaan ibadahnya. Sedangkan secara sosial, seseorang yang pernah melakukan umrah tentulah memiliki bekal yang cukup untuk melakukan perjalanan menunaikan ibadah tesebut. Karena berbeda dengan ibadah yang lain, menunaikan umrah membutuhkan dana yang tidak sedikit. Apalagi jika dilakukan berkali-kali tentu akan meningkatkan prestis secara sosial. Mereka yang mampu melaksanakan umrah berkali-kali tentu berada pada level ekonomi yang lebih mapan.

Fenomena melaksanakan umrah berkali-kali pada segmentasi masyarakat kelas menengah ke atas menjadi peluang bagi PPIHU untuk menciptakan program umrah berbeda dengan program yang fokus pada menyelenggarakan umrah semurah mungkin sehingga dapat diakses oleh lebih banyak calon jamaah. Umrah untuk kelas menengah tidak hanya fokus pada pelaksanaan umrah di Masjidil Haram namun juga dilengkapi dengan ziarah ke beberapa destinasi lain seperti berkunjung ke Masjilid Aqsa, beberapa tempat di Turki, kota di negara-negara Timur Tengah seperti Dubai dan Qatar. Program umrah plus umumnya dipasarkan dengan harga yang jauh lebih mahal daripada umrah reguler. Selain harga yang berbeda, kualitas pelayanan yang diberikanpun lebih eksklusif. Permasalahan yang terjadi pada umrah reguler jarang terjadi pada program umrah 
plus karena tidak menggunakan tiket penerbangan promo yang banyak digunakan oleh program umrah reguler. Penggunaan tiket penerbangan promo pada umrah reguler atau promo dilakukan oleh PPIHU untuk mendapatkan margin keuntungan. Sementara ketersediaanya sangat terbatas sehingga memunculkan masalah ketidak pastian waktu pemberangkatan jamaah umrah program reguler. Walaupun penundaan keberangkatan jamaah umrah reguler tidak selalu disebabkan oleh tidak tersedianya tiket promo, masalah lain yang sering menyebabkan penundaan adalah tidak terbitnya visa umrah dari kedutaan besar KSA.

Masalah yang dihadapi PPIHU tidak hanya berasal dari tiket dan visa, PPIHU juga harus memberikan pemahaman kepada calon jamaah mengenai teknis dan esensi pelaksanaan umrah. Sebelum berangkat malaksanakan umrah, PPIHU harus memberikan bimbingan manasik antara satu hingga tiga kali. Walaupun minimal dilakukan satu kali sebelum pemberangkatan namun jika orientasinya adalah memberikan pemahaman kepada calon jamaah tentu satu kali pertemuan tidaklah cukup. Minimal dilakukan dalam tiga kali pertemuan manasik sebelum keberangkatan umrah. Namun faktor efisiensi menyebabkan banyak PPIHU dengan program umrah promo hanya menyelenggarakan satu kali manasik umrah sebelum keberangkatan. Hal ini tentu berpotensi pada tidak maksimalnya pelaksanaan umrah yang dijalani oleh jamaah itu sendiri.

Masalah-masalah yang dihadapi inilah yang membedakan antara pengelolaan PPIHU dengan biro perjalanan wisata umum. Pengelolaan PPIHU tidak semata mengurus perjalanan jamaah dari Indonesia ke Masjidil Haram lalu kembali ke Indonesia. Dalam mengelola perjalanan umrah ada aspek spiritual yang menjadi esensinya. PPIHU harus dapat memberikan bimbingan kepada jamaahnya dalam melaksanakan rangkaian ibadah umrah dengan baik. Pembimbing umrah bukanlah seperti tourist guide yang bercerita tentang lokasi yang akan atau sedang dikunjungi namun harus dapat menjadi pembimbing spiritual bagi jamaah.

Peran pembimbing dalam pelaksanaan umrah sangat strategis dan menentukan kesuksesan pelaksanaan ibadah umrah. Pembimbing umrah tidak cukup hanya membekali jamaah dengan informasi teknis perjalanan maupun pelaksanaan ibadah umrah dalam kegiatan manasik sebelum keberangkatan saja, namun sepanjang perjalanan harus siap memberikan bimbingan secara berkelompok maupun individu (Saleh, 2008). Kualitas pembimbing turut menjadi daya tarik sebuah PPIHU dalam mempromosikan program umrah yang diselenggarakannya. Oleh karenanya seringkali terlihat promo pelaksanaan umrah bersama seorang tokoh terkenal seperti habib, ustadz maupun kiyai yang secara sosial memiliki daya tarik bagi jamaah. Pada sisi yang lain juga terlihat fenomena jamaah sebuah pengajian yang melaksanakan umrah secara bersama-sama dipandu oleh pengasuh pengajian tersebut. Bahkan muncul fenomena arisan umrah ataupun program kredit umrah. Dimana calon jamaah pada selama periode tertentu mengangsur pembiayaan umrah. 
Model program pembiayaan umrah dengan cicilan baik dalam bentuk arisan maupun kredit ada yang dinisiasi oleh PPIHU dalam rangka untuk mendapatkan calon jamaah yang lebih banyak. Dana yang dikumpulkan cenderung dapat diinvestasikan secara berjangka oleh PPIHU pada sektor lain sehingga berpotensi meningkatkan keuntungan finansial bagi PPIHU. Namun hal ini tentu saja tanpa resiko karena investasi yang dilakukan tidak menjamin keuntungan seratus persen. Dalam beberapa kasus yang terjadi PPIHU gagal memberangkatkan calon jamaahnya karena dana yang disetorkan oleh calon jamaah pada periode tertentu digunakan oleh PPIHU untuk investasi yang tidak menguntungkan. Sehingga pada saat menjelang periode pemberangkatan calon jamaah, PPIHU tidak dapat melaksanakan pemberangkatan karena dana calon jamaah sudah habis digunakan untuk investasi tersebut. Kasus ini tidak hanya terjadi pada PPIHU lokal, bahkan terjadi secara nasional seperti pada kasus first travel yang merugikan puluhan ribu calon jamaah.

Kasus-kasus yang terjadi secara nasional dan berulang dengan pola yang sama merupakan indikasi bahwa kontrol Kementerian Agama selaku regulator terhadap PPIHU selaku penyelenggara kegiatan ibadah umrah sangat lemah. Kewenangan yang diberikan oleh undang-undang nomor 13 tahun 2008 sangat terbatas. Selaku regulator pemerintah kementerian agama hanya memiliki kewenangan untuk memberikan dan mencabut ijin penyelenggaraan umrah pada tingkat Kementerian Agama pusat. Sedangkan Kementerian Agama di daerah baik tingkat Kota/Kabupaten ataupun wilayah hanya memiliki kewenangan untuk memberikan rekomendasi saja. Katerbatasan kewenangan ini menyebabkan Kementerian Agama kota/kabupaten tidak dapat melakukan tindakan apapun baik preventif maupun akuratif terhadap PPIHU yang terindikasi melakukan penyelewenangan dalam penyelenggaraan ibadah umrah.

Lemahnya kewenangan regulator juga berdampak pada tidak dipatuhinya standar pelayanan minimal yang ditetapkan oleh kemenag. Banyak PPIHU yang dalam pelaksanaannya kegiatannya berada di bawah standar minimal. Rendahnya kualitas pelayanan dipicu oleh murahnya biaya yang ditetapkan oleh PPIHU. Umrah murah merupakan cara PPIHU untuk mendapatkan calon jamaah sebanyak mungkin. Pada kasus ini, Kemenag Kota/Kabupaten tidak dapat melakukan penindakan kepada PPIHU di wilayahnya yang menawarkan program umrah murah di bawah standar pembiayaan minimal. Yang bisa dilakukan hanya memberikan informasi tentang standar pembiayaan minimal kepada masyarakat. Namun tidak semua masyarakat peduli dengan standar minimal pembiayaan karena daya tarik umrah murah lebih besar daripada kesadaran terhadap kualitas penyelenggaran umrah itu sendiri.

Pemberian ijin maupun pencabutannya berada pada kewenangan Kemenag Pusat dengan rekomendasi dari kemenag kota/kabupaten hanya berlaku bagi PPIHU yang memang telah memiliki ijin resmi. Sementara realitasnya tidak semua biro travel yang menyelenggarakan program umrah telah resmi menjadi PPIHU, 
dalam arti masih banyak PPIHU ilegal yang beroperasi di tengah masyarakat. Terhadap biro travel yang belum memiliki ijin kemenag kota/kabupaten bahkan tidak memiliki kewenangan sama sekali untuk melakukan tindakan apapun. Walaupun secara reguler kemenag kota/kabupaten telah memberikan informasi secara resmi kepada masyarakat tentang daftar PPIHU di wilayahnya, namun hal ini juga tidak berdampak signifikan di masyarakat. Karena tidak semua masyarakat memiliki kesadaran untuk mencari informasi mengenai legalitas biro travel penyelenggara umrah yang akan dipilihnya.

Lemahnya kewenangan sebagai regulator juga berdampak pada tidak tersedianya SDM secara khusus untuk menangani administrasi umrah yang masih menyatu dengan urusan haji pada seksi Penyelenggaraan Haji Umrah (PHU) di kantor kemenag kota/kabupaten. Selain kurangnya SDM, hingga saat ini belum tersedia sistem pendataan komprehensif terhadap jamaah umrah. Berbeda dengan jamaah haji yang telah terdata pada SISKOHAT, jamaah umrah masih tidak terdata secara jelas. Tidak tersedianya sistem kontrol yang memadai pada tingkat regulator tentu merupakan celah yang memicu terjadinya penyelewengan dalam kegiatan penyelenggaraan ibadah umrah.

Besarnya animo masyarakat dalam melaksanakan ibadah umrah harus selaras dengan peningkatan kualitas pelayanan terhadap jamaah. Setiap jamaah yang ingin melaksanakan umrah baik lewat PPIHU legal maupun ilegal harus mendapatkan jaminan pelayanan sesuai dengan standar yang telah ditetapkan oleh undang-undang. Tugas regulator adalah melakukan pengawasan terhadap pelaksanaan penyelenggaraan umrah baik dari sisi administrasi maupun teknis pelaksanaan, memastikan kegiatan dilakukan berdasarkan standar minimal pelayanan yang ditetapkan, melakukan kontrol kualitas atas penyelenggara, memberikan teguran jika ada indikasi pelanggaran, melindungi hak jamaah sebagai konsumen (Bertens, 2012).

Tugas dan fungsi regulator hanya bisa berjalan jika didukung oleh aturanaturan yang jelas dan dipahami. Sistem pendataan terintegrasi layaknya SISKOHAT harus dibangun untuk dapat mendukung fungsi regulasi. Tanpa data yang valid maka regulator akan kesulitas untuk menentukan arah kebijakan maupun pengambilan keputusan pada setiap masalah yang dihadapi. Selain itu ketersedian SDM dan sarana prasaran penunjang terlaksanakan tupoksi tersebut mutlak diperlukan (Nugroho, 2006). Oleh karenanya peningkatan kualitas dan kuantitas SDM pada seksi PHU di setiap kantor Kementerian Agama Kota/Kabupaten adalah keniscayaan dalam rangka penjaminan penyelenggaran pengelolaan ibadah umrah yang berkualitas di tingkat kota dan kabupaten hingga nasional.

Selaku regulator Kementerian Agama perlu menjalin kerjasama dengan asosiasi PPIHU untuk bersinergi dalam melaksanakan tupoksinya. Keberadaan asosiasi PPIHU akan memudahkan Kementerian Agama dalam mensosialisasikan aturan-aturan yang harus dipahami oleh semua PPIHU. Asosiasi PPIHU juga 
dapat berperan sebagai fasilitator untuk mensosialisasikan regulasi yang ada kepada masyarakat. Keterbukaan informasi mengenai regulasi diharapkan dapat meningkatkan kesadaran masyarakat akan pentingnya standarisasi pelayanan penyelenggaraan ibadah umrah. Karena yang paling dirugikan oleh pelayanan dan penyelenggaran tidak terstandar adalah jamaah sendiri. Peningkatan kesadaran tersebut pada akhirnya akan menyebabkan PPIHU memperbaiki mekanisme pelayanan dalam penyelenggaraan ibadah umrah. Karena tanpa kualitas layanan yang baik maka PPIHU akan ditinggalkan oleh jamaah yang merupakan konsumen mereka.

\section{PENUTUP}

Secara ringkas dapat dikatakan bahwa masalah dalam penyelenggaraan ibadah umrah di Kota Surakarta terjadi pada tiga pihak yaitu Kementerian Agama selaku regulator, PPIHU sebagai penyelenggara, dan jamaah sebagai konsumen. Masingmasing masalah saling terkait antara satu dengan yang lain. Namun, masalah yang paling mendasar adalah regulasi yang masih tidak jelas. Masalah regulasi ini menyebabkan berbagai masalah lainnya muncul dalam penyelenggaraan ibadah umrah. Oleh karenanya, perlu disusun sebuah regulasi yang baik dalam pengelolaan penyelenggaraan ibadah umrah. Regulasi yang mengatur secara jelas tupoksi masing-masing pihak yang terlibat dalam kegiatan tersebut. Kehadiran regulasi yang jelas yang mengatur pengelolaan dan penyelenggaraan ibadah umrah pada tingkat kota/kabupaten diharapkan dapat meminimalisir masalah-masalah yang saat ini banyak terjadi, baik di Kota Surakarta ataupun di tempat lain yang memiliki kondisi serupa.

\section{DAFTAR PUSTAKA}

Al-Albani, M. N. (1994). Haji dan Umrah seperti Rasulullah. Jakarta: Gema Insani. Azwar, B. (2007). Manfaat Haji dan Umrah bagi Kesehatan. Jakarta: Qultum Media. Bahjatulloh, Q. M. (2015). Pengembangan Wakaf Tunai Berbasis Umrah Di Pondok Pesantren Ta'Mirul Islam Surakarta. INFERENSI Jurnal Penelitian Sosial Keagamaan, 9(1), 137-158.

Bertens, K. (2012). Pengantar Etika Bisnis. Yogyakarta: Kanisius.

BPS. (2017). Jumlah Jemaah Haji yang Diberangkatkan ke Tanah Suci Mekah Menurut Provinsi, 2012-2015. Diakses August 13, 2017, dari https://www.bps.go.id/linkTableDinamis/view/id/894

Erianto, D. (2015). Menilik Sejarah Penyelenggaraan Ibadah Haji. Diakses 1 Januari 2017 dari http://print.kompas.com/baca/2015/10/07/MenilikSejarah-Penyelenggaraan-Haji

Ichwan, M. N. (2008). Governing Hajj: Politics of Islamic Pilgrimage Services in Indonesia Prior to Reformasi Era. Al-Jamiah: Journal of Islamic Studies, 46(1), 125-151. https://doi.org/10.14421/ajis.2008.461.125-151 
Kemenag. (2012). PP NOMOR 79 TAHUN 2012. Diakses 1 Januari 2017, dari https://kemenag.go.id/file/file/ProdukHukum/ohic1373876329.pdf

Kemenag. (2017). Kemenag Segera Reviu PMA. 18/2015 tentang Umrah. Diakses 13 Agustus 2017, dari https://kemenag.go.id/berita/read/504759/kemenagsegera-reviu-pma-18-2015-tentang-umrah

Lubis, C. (2017). Perang Tarif Jasa Penyelenggara Umrah. Diakses 13 Agustus 2017, dari http://telusur.metrotvnews.com/news-telusur/ybJeez4Nperang-tarif-jasa- penyelenggara-umrah

Masitah, D. (2015). Dinamika Bisnis Travel Umrah Se-Kota Pasuruan di Era Globalisasi. Iqtishadia: Jurnal Ekonomi \& Perbankan Syariah, 2(2), 242-261. https://doi.org/10.19105/iqtishadia.v2i2.850

Nugroho, R. (2006). Kebijakan Publik untuk Negara-negara Berkembang. Jakarta: Elex Media Komputindo.

PHU Kemenag. (2017a). Data Statistik Jemaah Haji Indonesia Tahun 1949 - 2014. Diakses 1 Januari 2017, dari https://haji.kemenag.go.id/v3/content/infografis-jemaah-haji-indonesiatahun-1949-2014

PHU Kemenag. (2017b). PMA Nomor 396 Tahun 2003. Diakses 3 Agustus, 2017, dari https:// haji.kemenag.go.id/v3/node/1679

Purbaningrat, S. H. (2012). Komunikasi Transendental Dalam Bisnis Travel Haji Dan Umrah Di Indonesia. Sosiobumaniora, 14(2), 186-197. https://doi.org/10.24198/sosiohumaniora.v14i2.5489

Purnomo, R. (2017). Ini Nama-nama Penyelenggara Perjalanan Ibadah Umrah dan Haji yang Dirilist Kemenag Surakarta. Diakses 1 Agustus 2017, dari http:/ / saudagar.info/berita-ini-namanama-penyelenggara-perjalananibadah-umrah-dan-haji-yang-dirilist-kemenag-surakarta.html

Republika. (2013). Menag: Kuota Haji Dikurangi 20 Persen. Diakses 1 Januari 2017, dari http://nasional.republika.co.id/berita/nasional/umum/13/06/12/moa23 m-menag-kuota-haji-dikurangi-20-persen

Ridha. (2014). Haji dan Umrah di Tengah Pertumbuhan Economic Of Leisure. Al-Adyan, 1(1), 73-90. Dari http://jurnalalqalam.or.id/index.php/Alqalam

Saleh, A. C. (2008). Penyelenggaraan Haji Era Reformasi : Analisis Internal Kebijakan Publik Departemen Agama. Jakarta: Alvabet.

Sari, I. F. (2015). Tinjauan Hukum Islam Terhadap Pembiayaan Haji Dan Umrah Melalui Sistem Marketing Di PT. Arminareka Perdana Yogyakarta. Economic: Journal of Economic and Islamic Law, 5(1), 93-117. Diakses dari http://ejournal.kopertais4.or.id/tapalkuda/index.php/economic/article/vi ew/952

Sucipto. (2013). Umrah Sebagai Gaya Hidup, Eksistensi Diri dan Komoditas Industri: Menyaksikan Perubahan Keagamaan Warga Kota. Kontekstualita: 
Jurnal Penelitian Sosial Keagamaan, 28(1), 21-49. Diakses dari http://ejournal.iainjambi.ac.id/index.php/kontekstualita/article/view/177

Thahir, H. (2016). Praktik Haji/Umrah sebagai Gaya Hidup : Pertumbuhan Bisnis Perjalanan Suci di Kota Makasar. Al-Qalam, 22(2), 127-139. Diakses dari http://jurnalalqalam.or.id/index.php/Alqalam/article/view/315

\section{Wawancara}

Anis, Staf Kemenag Kota Surakarta (Wawancara, 24/08/2017).

Azwar, Sekjen PERPUHI (Wawancara, 20/08/2017).

Farid, Managing Director PT. Amir Aliya Amalia (wawancara, 27/08/2017).

Muhammad Iqbal, Manajer Operasional Kharisma Haramain Indonesia (Wawancara, 26/08/2017)

Muslimin, Kepala Kantor Kementerian Agama Kota Surakarta (Wawancara, 22/08/2017) 